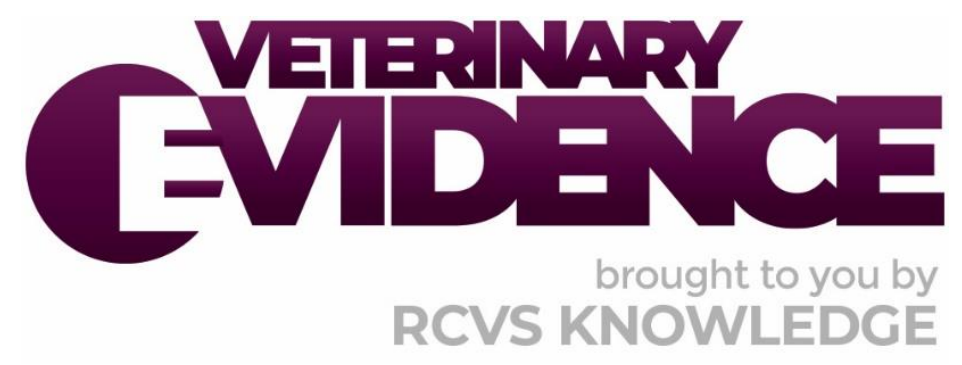

\title{
In bitches, is ovariectomy/ovariohysterectomy by laparoscopy less painful postoperatively than by midline open laparotomy?
}

\section{A Knowledge Summary by}

Chris Webb MA VetMB PgC(SAS) PgDip(VCP) MRCVS ${ }^{1^{*}}$ Julia Deutsch DipECVAA MRCVS ${ }^{2}$

\footnotetext{
${ }^{1}$ Fitzpatrick Referrals Ltd., Halfway Lane, Eashing, Godalming, GU7 2QQ

${ }^{2}$ Langford Vets, Small Animal Referral Hospital, University of Bristol Vet School, Langford House, North Somerset, BS40 5DU

* Corresponding Author (cwebb@fitzpatrickreferrals.co.uk)
}

ISSN: 2396-9776

Published: 05 Feb 2021

in: The Veterinary Evidence journal Vol 6, Issue 1

DOI: 10.18849/VE.V6I1.356

Reviewed by: Malcolm Ness (BVetMed CertSAO FRCVS ECVS) and Catrina Pennington (BVM \& MRCVS) 


\section{KNOWLEDGE SUMMARY}

\section{PICO question}

In bitches, is an ovariectomy/ovariohysterectomy by laparoscopy superior to an

ovariectomy/ovariohysterectomy by a midline surgical laparotomy in causing less postoperative pain?

\section{Clinical bottom line}

\section{Category of research question}

\section{Treatment}

\section{The number and type of study designs reviewed}

Seven papers were critically appraised. They comprised of three blinded randomised controlled trials, two non-blinded randomised controlled trials and two non-blinded non-randomised controlled trials

\section{Strength of evidence}

Weak

\section{Outcomes reported}

In bitches, ovariectomy/ovariohysterectomy by laparoscopy is superior to ovariectomy/ovariohysterectomy by a midline laparotomy in causing less postoperative pain

\section{Conclusion}

Despite the widely held belief that laparoscopic surgery is associated with less postoperative pain, the available veterinary literature only provides weak evidence to support this in bitches undergoing ovariectomy/ovariohysterectomy. There are many uncontrolled variables to consider across these underpowered studies including surgeon number (and experience), the choice of perioperative analgesia, method of pain scoring and the laparoscopic technique. It is therefore clear that laparoscopic procedures cannot be viewed equally and the strength of the answer to the clinical question may change based upon these variables. It is also important to note that the incidence of complications or the effect of the above variables on postoperative pain have not been critically reviewed and warrant careful consideration when deciding on a laparoscopic approach

\section{How to apply this evidence in practice}

The application of evidence into practice should take into account multiple factors, not limited to: individual clinical expertise, patient's circumstances and owners' values, country, location or clinic where you work, the individual case in front of you, the availability of therapies and resources.

Knowledge Summaries are a resource to help reinforce or inform decision making. They do not override the responsibility or judgement of the practitioner to do what is best for the animal in their care. 


\section{Clinical Scenario}

During a rabies vaccination appointment, you discuss with your client about the benefits of spaying her young French bulldog bitch in the near future. She enquires about a keyhole approach as your practice started performing laparoscopic spays last year. Her previous practice was not in support of the technique as the veterinary surgeons had many years of great success with small incisions. The client feels her bitch is very sensitive however, so would like to know if there is any evidence that she will be in any less pain following a laparoscopic approach.

\section{The evidence}

Seven studies were identified that compared postoperative pain in bitches spayed by laparoscopy with bitches spayed by a traditional midline laparotomy. They comprised of three blinded randomised controlled trials, two non-blinded randomised controlled trials and two non-blinded non-randomised controlled trials. One paper provided weak-moderate evidence and the remaining six papers provided weak evidence to support laparoscopy as being superior to an open midline laparotomy in causing less postoperative pain.

\section{Summary of the evidence}

\begin{tabular}{|c|c|}
\hline \\
\hline $\begin{array}{l}\text { Dalmolin et al. (2020) } \\
\text { Population: }\end{array}$ & $\begin{array}{l}\text { Female mongrel dogs } \\
\text { Inclusion criteria } \\
\text { Intact bitches, assessed to be healthy on general physical } \\
\text { examination and blood evaluation (haematology, creatinine, } \\
\text { albumin, alkaline phosphatase and alanine aminotransferase). } \\
\text { Group characteristics } \\
\text { - Age 1-4 years } \\
\text { - Weight } 16.19 \pm 3.73 \mathrm{~kg}\end{array}$ \\
\hline Sample size: & 14 dogs \\
\hline Intervention details: & $\begin{array}{l}\text { - Both groups were premedicated intramuscularly with } \\
\text { acepromazine } 0.05 \mathrm{mg} / \mathrm{kg} \text { and, following induction, received } \\
\text { an intravenous loading dose of fentanyl } 1.25 \mathrm{mcg} / \mathrm{kg} \text { over } 5 \\
\text { minutes followed by constant rate infusion at } 15 \mathrm{mcg} / \mathrm{kg} / \mathrm{h} \text {. } \\
\text { - } \quad \text { All procedures were performed by the same surgeon. } \\
\text { - Laparoscopic assisted ovariohysterectomy ( } \mathrm{LOH} \text { ( } \mathrm{n}=7 \text { ): Two } \\
11 \mathrm{~mm} \text { ports were placed on the midline, through the } \\
\text { umbilicus and the prepubic area. Bipolar cauterisation and } \\
\text { transection of the ovarian pedicles and suspensory ligament } \\
\text { was performed (Powerblade }{ }^{\circledR} \text { ) and double ligatures applied } \\
\text { to the uterine body and vessels. } \\
\text { Open ovariohysterectomy (OHE) ( } \mathrm{n}=7 \text { ): A midline incision } \\
\text { was performed approximating } 1 / 3 \text { of the umbilicopubic } \\
\text { distance. Ovarian pedicle and uterine body ligation was } \\
\text { performed with double ligation ( } 2-0 \text { polyglactin } 910 \text { ) using a } \\
\text { modified three clamp technique. } \\
\text { - At the end of the procedure, all patients received } \\
\text { intravenous dipyrone } 25 \mathrm{mg} / \mathrm{kg} \text { and scopolamine } 0.2 \mathrm{mg} / \mathrm{kg} \text {, } \\
\text { and meloxicam } 0.2 \mathrm{mg} / \mathrm{kg} \text {. } \\
\text { - Wounds were dressed similarly for both groups. } \\
\text { - Further doses of dipyrone and scopolomine were given four }\end{array}$ \\
\hline
\end{tabular}




\begin{tabular}{|c|c|}
\hline & $\begin{array}{l}\text { times daily and meloxicam given once daily, both } \\
\text { subcutaneously. }\end{array}$ \\
\hline Study design: & Prospective, blinded, randomised, controlled trial \\
\hline Outcome studied: & $\begin{array}{l}\text { - Surgical time. } \\
\text { - Postoperative pain scores using visual analogue scale (VAS), } \\
\text { University of Melbourne Pain Scale (UMPS) and short form } \\
\text { Glasgow Composite Measure Pain Scale (CMPS-SF) at 2, 4, 6, } \\
8,12,18,24,36,48 \text { and } 72 \text { hours after surgery by three } \\
\text { trained assessors. } \\
\text { - Requirement for rescue analgesia ( } 0.5 \mathrm{mg} / \mathrm{kg} \text { morphine } \\
\text { sulphate) as determined by two or three assessors scoring } \\
\text { greater than } 50 \mathrm{~mm} \text { on VAS, } 7 / 27 \text { on UMPS, or } 12 / 24 \text { on } \\
\text { CMPS-SF. } \\
\text { - Time to first voluntary eating and defaecation. }\end{array}$ \\
\hline $\begin{array}{l}\text { Main findings: } \\
\text { (relevant to PICO question): }\end{array}$ & $\begin{array}{l}\text { - There was no significant difference in pain scores between } \\
\text { groups at any point using VAS. } \\
\text { - Pain scores were significantly lower in LOH group at } 6 \text { hours } \\
\text { using UMPS ( } p=0.01 \text { ). } \\
\text { - Pain scores were significantly lower in LOH group at } 36 \text { and } \\
48 \text { hours using CMPS-SF ( } p<0.01 \text { ). } \\
\text { - Time to first spontaneous food intake was significantly } \\
\text { earlier in LOH group ( } p=0.01 \text { ). } \\
\text { - Time to first spontaneous defaecation was earlier in LOH } \\
\text { group but but not significant ( } p=0.14 \text { ). } \\
\text { - No rescue analgesia was required at any point. }\end{array}$ \\
\hline Limitations: & $\begin{array}{l}\text { - Surgical description was limited. } \\
\text { - Pain scoring was performed by three different assessors } \\
\text { with only light }(1 \times 2) \text { and moderate }(1 \times 3,2 \times 3) \text { agreement. } \\
\text { - None of the pain scores capture feeding or defaecation as a } \\
\text { parameter of pain. } \\
\text { - Small study size with only seven animals in each group. } \\
\text { - No reporting of confidence intervals for pain scores. }\end{array}$ \\
\hline
\end{tabular}

\section{Coutinho et al. (2018)}

Population: Female dogs from animal protection association of Taquaritinga, São Paulo, Brazil

Inclusion criteria

- Intact, anoestrus bitches, assessed to be healthy on general physical examination, abdominal ultrasound, and blood (haematology, creatinine and alanine aminotransferase) and urine evaluation.

- Free of intraoperative complications $-4 / 24$ bitches (two from each group) were removed from further analysis due to intraoperative complications. 


\begin{tabular}{|c|c|}
\hline & $\begin{array}{l}\text { Group characteristics } \\
\text { - Mean age } 2.4 \pm 1.0 \text { years } \\
\text { - Weight } 9.2 \pm 2.5 \mathrm{~kg}\end{array}$ \\
\hline Sample size: & 24 dogs \\
\hline Intervention details: & $\begin{array}{l}\text { - Both groups premedicated intramuscularly with morphine } \\
0.5 \mathrm{mg} / \mathrm{kg} \text { and chlorpromazine } 0.5 \mathrm{mg} / \mathrm{kg} \text {. } \\
\text { LOH ( } \mathrm{n}=12 \text { ): a midline prepubic } 11 \mathrm{~mm} \text { single port was } \\
\text { placed using an open technique and capnoperitoneum } \\
\text { performed with a maximum insufflation pressure of } 10 \\
\text { mmHg. Bipolar cauterisation and transection of the ovarian } \\
\text { pedicles were performed (Powerblade }{ }^{\circledR} \text { ). The uterine body } \\
\text { was identified and transfixed using poliglecaprone } 25 \text { and } \\
\text { transected. The abdominal muscles were closed in the same } \\
\text { suture and appositional nylon skin sutures were placed. } \\
\text { OHE ( } \mathrm{n}=12 \text { ): a } 30 \text { mm midline incision was made from } 1 \mathrm{~cm} \\
\text { caudal to the umbilicus. The ovaries were exteriorised with } \\
\text { the help of a snook hook and a transfixing ligature placed in } \\
\text { the pedicles prior to transection. The cervix was ligated with } \\
\text { a Miller's knot and transected prior to routine abdominal } \\
\text { closure. Poliglecaprone } 25 \text { was used for all internal sutures } \\
\text { and the skin was apposed using simple interrupted nylon } \\
\text { sutures. } \\
\text { Wounds were dressed similarly for both groups. }\end{array}$ \\
\hline Study design: & Prospective, blinded, randomised, controlled trial \\
\hline Outcome studied: & $\begin{array}{l}\text { Postoperative pain scores (as soon as animals regained } \\
\text { walking ability and } 0.5,1,2,4,8,12,16 \text { and } 24 \text { hours later) } \\
\text { using VAS and UMPS - assessors blinded to the surgical } \\
\text { group. } \\
\text { Requirement for rescue analgesia (VAS }>50 \mathrm{~mm} \text { and/or } \\
\text { UMPS }>12 / 27 \text { ). } \\
\text { Blood glucose and serum CRP concentrations preoperatively } \\
\text { and } 1,4,12 \text { and } 24 \text { hours after the end of the surgical } \\
\text { procedure. } \\
\text { Voluntary food ingestion assessed by direct observation } \\
\text { during the } 24 \text { hour postoperative period. }\end{array}$ \\
\hline $\begin{array}{l}\text { Main findings: } \\
\text { (relevant to PICO question): }\end{array}$ & $\begin{array}{l}\text { - Intensity of postoperative pain was lower for the } \mathrm{LOH} \text { group at } \\
\text { most time points but not statistically significant }(p>0.05) \text {. } \\
\text { - Rescue analgesia was required for } 3 / 20 \text { dogs (LOH } 1 / 10 ; \text { OHE } \\
2 / 10 \text { ) but was not significant between groups }(p>0.05) \text {. } \\
\text { - Animals in the LOH group ate earlier and in greater proportion } \\
\text { than those in the OHE group ( } p=0.02 \text { ). } \\
\text { - Serum CRP was similar between groups ( } p>0.05) \text {. } \\
\text { - Blood glucose was higher in OHE group from } 1 \text { hour until the } \\
\text { end of measurements when compared to } \mathrm{LOH} \text { group }(p=0.03) \text {. }\end{array}$ \\
\hline Limitations: & $\begin{array}{l}\text { - Breeds are not reported. } \\
\text { - The weight and ages are not reported for each group. } \\
\text { - Elimination of complications from further assessment - } \\
\text { these are important to consider when performing studies to } \\
\text { support laparoscopy. }\end{array}$ \\
\hline
\end{tabular}




\begin{tabular}{|l|l|}
\hline & $\begin{array}{l}\text { - Pain scoring was performed by two observers creating inter- } \\
\text { observer bias. }\end{array}$ \\
- Neither VAS nor UMPS capture feeding behaviour as a \\
- Sarameter of pain. \\
- Small study size with only 10 animals in each group. \\
\hline
\end{tabular}

\begin{tabular}{|c|c|}
\hline \multicolumn{2}{|l|}{ Vasiljevic et al. (2015) } \\
\hline Population: & $\begin{array}{l}\text { Client-owned medium and large breed female dogs } \\
\text { Inclusion criteria } \\
\text { - Intact bitches, assessed to be healthy on general physical } \\
\text { - examination, haematology and biochemistry. } \\
\text { American Society of Anaesthesiologists Category I (ASA I). } \\
\text { Group characteristics } \\
\text { - Age } 0.58-3 \text { years } \\
\text { - Weight 5-35 kg }\end{array}$ \\
\hline Sample size: & 20 dogs \\
\hline Intervention details: & $\begin{array}{l}\text { - Both groups premedicated with carprofen } 4 \mathrm{mg} / \mathrm{kg} \\
\text { subcutaneously and medetomidine } 0.03 \mathrm{mg} / \mathrm{kg} \\
\text { intravenously } \\
\text { - LOV ( } \mathrm{n}=10) \text {. } \\
\text { - OVE }(\mathrm{n}=10) . \text { Patients received ketamine } 2 \mathrm{mg} / \mathrm{kg} \\
\text { intravenously at the time of withdrawal of the left ovary. } \\
\text { - Atipamazole } 0.015 \mathrm{mg} / \mathrm{kg} \text { was given intramuscularly at the } \\
\text { end of surgery in both groups. }\end{array}$ \\
\hline Study design: & Prospective, non-blinded, randomised, controlled trial \\
\hline Outcome studied: & $\begin{array}{l}\text { - Intraoperative pain estimation at certain time points by } \\
\text { measuring changes in heart rate, respiratory rate, arterial } \\
\text { blood pressure and body temperature. } \\
\text { Postoperative pain using a multifactor pain scoring system } \\
\text { (0-9 scale) at } 0.25,0.5,1,3 \text { and } 6 \text { hours postoperatively. }\end{array}$ \\
\hline $\begin{array}{l}\text { Main findings: } \\
\text { (relevant to PICO question): }\end{array}$ & $\begin{array}{l}\text { OVE group: } \\
\text { - No dogs were free of pain (score } 0 \text { ) at any time point. } \\
\text { - Number of dogs experiencing mild pain (score 1-3) reduced } \\
\text { from five to one over the observation period. } \\
\text { - Number of dogs experiencing moderate pain (score 4-6) and } \\
\text { severe pain (score 7-10) increased from four to seven, and } \\
\text { from one to two over the observation period, respectively. } \\
\text { LOV group: } \\
\text { - Up to } 0.5 \text { hours, all dogs experienced mild or moderate pain. } \\
\text { - From } 1 \text { to } 6 \text { hours, all dogs experienced either no pain or } \\
\text { mild pain. } \\
\text { - A maximum of two dogs experienced moderate pain, and no } \\
\text { dogs experienced severe pain at any time point. }\end{array}$ \\
\hline
\end{tabular}




\begin{tabular}{|c|c|}
\hline Limitations: & $\begin{array}{l}\text { - } \quad \text { Breed, mean age and mean weight are not provided. } \\
\text { - } \quad \text { OVE group received additional intraoperative analgesia. } \\
\text { - } \quad \text { No opioid in the premedication. } \\
\text { - The name of the pain scoring system was not stated or } \\
\text { referenced; described as a } 0-9 \text { scale but data presented as } \\
0-10 \text { - raises questions over whether this is just an error or } \\
\text { if the remainder of data/reporting is liable to contain errors } \\
\text { - Slower postoperative recovery in the OVE group may affect } \\
\text { - } \quad \text { The observer was not blinded to the surgical group. } \\
\text { - No statistical analysis of postoperative pain scores, only } \\
\text { - } \quad \text { intraoperative parameters. } \\
\text { - No reporting of confidence intervals. } \\
\text { - Questionable ethics as no intervention was set for rescue } \\
\text { analgesia during the } 6 \text { hour observation - } 2 / 20 \text { dogs (10\%) } \\
\text { were in severe pain and only received analgesia at the end } \\
\text { of the study. }\end{array}$ \\
\hline
\end{tabular}

Freeman et al. (2010)

\begin{tabular}{|c|c|}
\hline Population: & $\begin{array}{l}\text { Female dogs; combination of research and shelter animals } \\
\text { Inclusion criteria } \\
\text { - Healthy bitches. } \\
\text { - Haematocrit, total protein and blood glucose measurement. } \\
\text { Group characteristics } \\
\text { LOV } 18.8 \pm 4.4 \mathrm{~kg} \text {; OVE } 20.4 \pm 3.8 \mathrm{~kg}\end{array}$ \\
\hline Sample size: & 30 dogs; research animals $n=10$, shelter animals $n=20$ \\
\hline Intervention details: & $\begin{array}{l}\text { - All animals were subject to the same anaesthetic protocol } \\
\text { but this was not described. } \\
\text { - } n=10 \text { research animals) Natural orifice transluminal } \\
\text { endoscopic surgery (NOTES): This was performed via a } \\
\text { previously described transgastric approach. Abdominal } \\
\text { insufflation was provided by air from the endoscope and } \mathrm{CO}_{2} \\
\text { via a percutaneous catheter from an automated insufflator } \\
\text { set to } 12-14 \mathrm{mmHg} \text {. A } 3.0 \times 4.5 \mathrm{~cm} \text { hexagonal snare } \\
\text { (AcuSnare }{ }^{\circledR} \text { ) with monopolar electrocautery was used to } \\
\text { coagulate and cut each ovarian pedicle. After visual } \\
\text { inspection to ensure each ovary was completely removed, } \\
\text { the gastrotomy was closed with prototype T-fasteners. This } \\
\text { technique will not be commented on further as it is not } \\
\text { being investigated by this Knowledge Summary. } \\
\text { LOV ( } \mathrm{n}=10 \text { shelter animals): A } 10 \text { mm port was placed at the } \\
\text { umbilicus and a midline } 5 \mathrm{~mm} \text { port placed } 5 \mathrm{~cm} \text { caudal to } \\
\text { this. Capnoperitoneum was created using an automated } \\
\text { insufflator set to } 12-14 \mathrm{mmHg} \text {. Each ovary was elevated }\end{array}$ \\
\hline
\end{tabular}




\begin{tabular}{|c|c|}
\hline & $\begin{array}{l}\text { with grasping forceps and suspended from the body wall } \\
\text { using a percutaneous needle or weighted hook. A } 5 \mathrm{~mm} \\
\text { harmonic scalpel was then used to cut and coagulate the } \\
\text { ovarian attachments. Ovaries were removed from the } \\
\text { umbilical port, followed by ports and the sites closed in } \\
\text { three layers (suture and pattern not specified.) } \\
\text { OVE ( } \mathrm{n}=10 \text { shelter animals): A } 40-60 \mathrm{~mm} \text { midline incision } \\
\text { was made } 3 \mathrm{~cm} \text { caudal to the umbilicus. A snook hook was } \\
\text { used to assist exteriorisation of an ovary and a three clamp } \\
\text { technique was used to place two ligatures on the pedicle. } \\
\text { The pedicle was transected, the oviduct ligated and the } \\
\text { ovary removed. The midline incision was closed routinely in } \\
\text { three layers. } \\
\text { All dogs received intramuscular hydromorphone } 0.05 \mathrm{mg} / \mathrm{kg} \\
\text { at } 0 \text { and } 6 \text { hours postoperatively. }\end{array}$ \\
\hline Study design: & Prospective, non-blinded, non-randomised, controlled trial \\
\hline Outcome studied: & $\begin{array}{l}\text { - Surgical time. } \\
\text { - Pain score preoperatively and postoperatively at } 2,4,6,12 \text {, } \\
\text { 18, 24, } 36,48 \text { and } 72 \text { hours after extubation using UMPS. } \\
\text { - } \quad \text { Requirement for rescue analgesia (UMPS }>10 / 27 \text { ). } \\
\text { - } \text { aciceptive threshold was assessed (same time points) using } \\
\text { a previously described abdominal pressure cuff technique. } \\
\text { - Physiological parameters, blood glucose and blood cortisol } \\
\text { concentrations (same time points). } \\
\text { - Surgical stress markers (serum IL-6 and CRP) at } 0,2,6,12 \text {, } \\
24,36 \text { and } 72 \text { hours postoperatively. }\end{array}$ \\
\hline $\begin{array}{l}\text { Main findings: } \\
\text { (relevant to PICO question): }\end{array}$ & $\begin{array}{l}\text { - Mean LOV group pain scores equal or lower than OVE group } \\
\text { at all postoperative time points. } \\
\text { - Cumulative pain scores for LOV group were significantly } \\
\text { lower ( } p<0.05 \text { ) than OVE group at } 18,36 \text { and } 72 \text { hours } \\
\text { postoperatively. } \\
\text { - } \quad \text { Rescue analgesia was not required in any of the groups. } \\
\text { - Nociceptive threshold for OVE group significantly lower } \\
\text { ( } p<0.05 \text { ) than LOV group at } 4 \text { and } 12 \text { hours postoperatively. } \\
\text { - IL-6 and CRP were not significantly increased over baseline } \\
\text { in both LOV and OVE groups. } \\
\text { - Cortisol increased from baseline at } 2 \text { hours in both LOV and } \\
\text { OVE groups. } \\
\text { - Glucose elevated from baseline at many time points in both } \\
\text { LOV and OVE groups. }\end{array}$ \\
\hline Limitations: & $\begin{array}{l}\text { - No data on age or breed of animals. } \\
\text { - The general anaesthetic protocol was not stated. } \\
\text { - } \text { population, however, their comparison should not be } \\
\text { affected. } \\
\text { - Number of surgeons and their experience was not reported. } \\
\text { - Pain scoring was performed by two observers, creating } \\
\text { inter-observer bias. } \\
\text { - It is not clear whether observers were blinded to the } \\
\text { treatment group. }\end{array}$ \\
\hline
\end{tabular}




\begin{tabular}{|l|l|}
\hline - It is not clear whether the same observers were involved \\
with nociceptive threshold testing, but the same issue of \\
multiple non-blinded assessors would apply. \\
- The stress of blood sampling may affect nociceptive \\
threshold testing (the latter was performed immediately \\
after the former). \\
- There is no discussion of the statistical significance between \\
LOV and OVE - they are only presented as symbols in the \\
figures so may be missed by the reader. \\
- Small study size with only 10 animals in each group. \\
No reporting of confidence intervals.
\end{tabular}

Devitt et al. (2005)

\begin{tabular}{|c|c|}
\hline Population: & $\begin{array}{l}\text { Female dogs scheduled for adoption through local animal shelters } \\
\text { Inclusion criteria } \\
\text { Intact, bitches, assessed to be healthy on physical examination and } \\
\text { blood parameters (haematology and biochemistry). } \\
\text { Group characteristics } \\
\text { - Mean age } 1.5 \pm 0.93 \text { years (OHE) and } 1.45 \pm 0.78 \text { years (LOH) } \\
\quad(p=0.444) \\
\text { - Mean weight } 22.0 \pm 5.6 \mathrm{~kg}(\mathrm{OHE}) \text { and } 22.1 \pm 5.0 \mathrm{~kg}(\mathrm{LOH}) \\
(p=0.488)\end{array}$ \\
\hline Sample size: & 20 dogs \\
\hline Intervention details: & $\begin{array}{l}\text { Both OHE and LOH groups premedicated subcutaneously } \\
\text { with glycopyrrolate } 0.01 \mathrm{mg} / \mathrm{kg} \text {, acepromazine } 0.03 \mathrm{mg} / \mathrm{kg} \\
\text { and morphine } 0.2 \mathrm{mg} / \mathrm{kg} \text {; bupivacaine } 2 \mathrm{mg} / \mathrm{kg} \text { was infused } \\
\text { into the surgical site (OHE) or divided between surgical sites } \\
\text { (LOH) prior to incision. } \\
\text { - } \mathrm{LH} \text { ( } \mathrm{n}=10 \text { ): Patients were positioned in a hinged v-shaped } \\
\text { trough to enable rotation to left and right lateral } \\
\text { recumbency. Capnoperitoneum was created using a Veress } \\
\text { needle technique and mechanical insufflator set to } 10-13 \\
\text { mmHg. The ovarian vasculature was cauterised and } \\
\text { transected using multifunction bipolar gasping forceps via a } \\
12 \mathrm{~mm} \text { cannula at the umbilicus ( } 11 \text { mm laparoscope and } 6 \\
\text { mm working channel). A } 5 \text { or } 12 \text { mm cannula was then } \\
\text { inserted in the midline (approximately } 4-5 \text { mm cranial to the } \\
\text { pubis) under direct visualization to exteriorise the ovaries } \\
\text { and uterus. The body of the uterus was ligated, transfixed } \\
\text { and divided before returning the uterine stump to the } \\
\text { abdomen and monitoring for haemostasis with the } \\
\text { laparoscope. Port sites were closed in two layers with } \\
\text { absorbable monofilament suture and nylon. } \\
\text { OHE ( } \mathrm{n}=10 \text { ): This was performed via midline incision } \\
\text { approximating } 1 / 3 \text { of the umbilicopubic distance (no further } \\
\text { description provided). }\end{array}$ \\
\hline
\end{tabular}




\begin{tabular}{|c|c|}
\hline & $\begin{array}{l}\text { - All dogs received } 0.2 \mathrm{mg} / \mathrm{kg} \text { morphine subcutaneously } \\
\text { before extubation. }\end{array}$ \\
\hline Study design: & Prospective, non-blinded, randomised, controlled trial \\
\hline Outcome studied: & $\begin{array}{l}\text { - Surgical time. } \\
\text { - } \text { Requirement for mechanical ventilation under anaesthesia. } \\
\text { paediatric pain scoring system) at } 1,2,4,6,12 \text { and } 24 \text { hours } \\
\text { after extubation. } \\
\text { - Requirement for rescue analgesia (pain score } 6 / 19 \text { or } \\
\text { higher). } \\
\text { - Serum glucose and cortisol concentration at the same time } \\
\text { points above. }\end{array}$ \\
\hline $\begin{array}{l}\text { Main findings: } \\
\text { (relevant to PICO question): }\end{array}$ & $\begin{array}{l}\text { Pain scores were higher at all time points for OHE group } \\
\text { compared to } \mathrm{LOH} \text { group ( } p=0.001) \text {. } \\
\text { - } 9 / 10 \text { OHE cases required additional pain relief based on the } \\
\text { pain score compared to } 0 / 10 \mathrm{LOH} \text { cases ( } p=0.001 \text {; relative } \\
\text { risk } 10.0[95 \% \mathrm{Cl}, 1.6-64.2] \text { ). } \\
\text { - Cortisol concentrations were significantly elevated from } \\
\text { baseline in OHE group at } 1 \text { and } 2 \text { hours but not in } \mathrm{LOH} \\
\text { group. } \\
\text { - Glucose concentrations were significantly elevated from } \\
\text { baseline in OHE group at } 1,2,4 \text { and } 6 \text { hours, and in } \mathrm{LOH} \\
\text { group at hour } 1 \text { only. }\end{array}$ \\
\hline Limitations: & $\begin{array}{l}\text { - } \quad \text { No breed information provided. } \\
\text { - Uimited description of open surgery. } \\
\text { - } \text { for assessing human paediatric pain. } \\
\text { - Pain scoring was performed by two observers, creating } \\
\text { inter-observer bias. } \\
\text { - Small study size with only } 10 \text { animals in each group. }\end{array}$ \\
\hline
\end{tabular}

Hancock et al. (2005)

\begin{tabular}{|c|c|}
\hline Population: & $\begin{array}{l}\text { Purpose bred female Beagles } \\
\text { Inclusion criteria } \\
\text { Intact, Beagle bitches, with normal physical examination findings, } \\
\text { blood parameters (haematology and biochemistry) and urinalysis } \\
\text { results. } \\
\text { Group characteristics } \\
\text { Mean weight } 11 \mathrm{~kg} \text { (range: } 10.1-12.2 \mathrm{~kg} \text { ) }\end{array}$ \\
\hline Sample size: & 16 dogs \\
\hline Intervention details: & $\begin{array}{l}\text { Both groups premedicated subcutaneously with } \\
\text { acepromazine } 0.03 \mathrm{mg} / \mathrm{kg} \text { and morphine sulphate } 0.25 \\
\mathrm{mg} / \mathrm{kg} \text {. } \\
\text { - } \mathrm{LOH}(\mathrm{n}=8) \text { : An open technique was used to place a } 5 \mathrm{~mm} \\
\text { cannula and capnoperitoneum created using a mechanical }\end{array}$ \\
\hline
\end{tabular}




\begin{tabular}{|c|c|}
\hline & $\begin{array}{l}\text { insufflator set to } 10 \mathrm{mmHg} \text {. Babcock forceps and a harmonic } \\
\text { scalpel were used (via a 3-port technique) to transect } \\
\text { ovarian pedicles and the uterus cranial to the cervix. The } \\
\text { umbilical port incision was closed with simple interrupted } \\
\text { sutures in the linea alba (2-0 polydiaxanone [PDS]), subcutis } \\
\text { (3-0 PDS) and skin (3-0 nylon). Paramedian port incisions } \\
\text { were closed with simple interrupted muscular (3-0 PDS) and } \\
\text { skin (3-0 nylon) sutures. } \\
\text { OHE ( } \mathrm{n}=8 \text { ): A } 60 \mathrm{~mm} \text { midline incision was made starting } 1 \mathrm{~cm} \\
\text { caudal to the umbilicus. A modified three clamp technique } \\
\text { for each ovary and pedicle ligation was performed with 2-0 } \\
\text { PDS. The linear alba was closed in simple continuous pattern } \\
\text { (2-0 PDS), followed by the subcutis (3-0 PDS), and skin (3-0 } \\
\text { nylon). } \\
\text { All dogs received } 0.5 \mathrm{mg} / \mathrm{kg} \text { morphine sulphate } \\
\text { subcutaneously at extubation. }\end{array}$ \\
\hline Study design: & Prospective, blinded, block randomised, controlled trial \\
\hline Outcome studied: & $\begin{array}{l}\text { - } \quad \text { Surgical time. } \\
\text { - Physiological parameters. } \\
\text { - Pain scores using UMPS at } 2,6,12,24,48 \text { and } 72 \text { hours } \\
\text { postoperatively. } \\
\text { - } \quad \text { Requirement for rescue analgesia (UMPS } 10 / 27 \text { or higher). } \\
\text { - Blood glucose, CPK and plasma cortisol concentrations } \\
\text { (same time points). } \\
\text { - Nociceptive threshold using an abdominal pressure cuff by } \\
\quad \text { the same handler (same time points). }\end{array}$ \\
\hline $\begin{array}{l}\text { Main findings: } \\
\text { (relevant to PICO question): }\end{array}$ & $\begin{array}{l}\text { - Mean pain scores were significantly lower for } \mathrm{LOH} \text { group } \\
\text { ( } p=0.0001 \text { ) at all postoperative time points (although } 95 \% \mathrm{Cl} \\
\text { overlapped at hour } 2 \text { and } 48 \text { ). } \\
\text { - Mean nociceptive threshold was significantly higher for } \mathrm{LOH} \\
\text { group ( } p=0.0002 \text { ) at all postoperative times except } 72 \text { hours. } \\
\text { - } \quad \text { No dogs required rescue analgesia at any point. } \\
\text { - Though mean } \mathrm{LOH} \text { group surgical time was significantly } \\
\text { longer ( } p=0.0001 \text { ), this had no significant nuisance effects on } \\
\text { any of the measured pain variables at any time. } \\
\text { - Mean cortisol concentration for LOH group was significantly } \\
\text { lower than for OHE group at hour } 2 \text { ( } p=0.0001 \text { ). } \\
\text { Mean blood glucose and CPK concentrations were not } \\
\text { significantly different between groups at any time. }\end{array}$ \\
\hline Limitations: & $\begin{array}{l}\text { - Three surgeons were responsible for the procedures of } \\
\text { varying levels of experience. } \\
\text { - Mean age and weight not reported for each group. } \\
\text { - Small study size with only eight animals in each group. }\end{array}$ \\
\hline
\end{tabular}




\begin{tabular}{|c|c|}
\hline & \\
\hline Population: & $\begin{array}{l}\text { Female dogs; combination of client-owned and shelter animals } \\
\text { Inclusion criteria } \\
\text { - Intact bitches with normal blood glucose, blood urea } \\
\text { nitrogen, packed cell volume and total plasma protein } \\
\text { concentration. } \\
\text { - Six animals were not included in further analysis as they did } \\
\text { not receive ketoprofen at the end of surgery. } \\
\text { Group characteristics } \\
\text { - LOH: age 4-36 months (mean } 10.5 \text { months; median } 8 \\
\text { months); weight } 10-38 \mathrm{~kg} \text { (mean, } 17.9 \mathrm{~kg} \text { ); } 1 / 16 \text { had whelped } \\
\text { previously, } 15 / 16 \text { nonparous. Vaccinated and negative for } \\
\text { heartworm and intestinal parasites. } \\
\text { OHE: age 4-96 months (mean } 19 \text { months; median } 6 \\
\text { months); weight } 2.4-24 \mathrm{~kg} \text { (mean } 12.1 \mathrm{~kg} \text { ) }\end{array}$ \\
\hline Sample size: & 34 dogs; client-owned $n=18$, shelter animals $n=16$ \\
\hline Intervention details: & $\begin{array}{l}\text { Premedication in both groups was a combination of either } \\
\text { intramuscular morphine } 1 \mathrm{mg} / \mathrm{kg} \text { and glycopyrrolate } 0.01 \\
\mathrm{mg} / \mathrm{kg} \text {, or morphine } 1 \mathrm{mg} / \mathrm{kg} \text {, glycopyrrolate } 0.01 \mathrm{mg} / \mathrm{kg} \text { and } \\
\text { acepromazine } 0.1 \mathrm{mg} / \mathrm{kg} \text {. } \\
\text { - Ketamine was included as an induction agent in some } \\
\text { animals (LOH= } 4 / 16, \mathrm{OHE}=1 / 18 \text { ). } \\
\text { - } \mathrm{LOH} \text { ( } \mathrm{n}=16 \text { shelter animals): Capnoperitoneum was created } \\
\text { to a maximum pressure of } 12-14 \mathrm{mmHg} \text { via a Veress needle } \\
\text { placed at the umbilicus. Four } 5 \mathrm{~mm} \text { ports were placed in } \\
\text { each quadrant and the ovarian pedicles disrupted using } \\
\text { bipolar cautery. Pedicles were then double ligated using } 4-0 \\
\text { surgical wire (TouchéTM suturing system) prior to complete } \\
\text { transection using bipolar electrocautery. The same } \\
\text { technique was then used to remove the uterus just cranial } \\
\text { to the cervix. PDS muscle sutures and nylon skin sutures } \\
\text { were then placed at each incisional site. All surgery } \\
\text { performed by a single vet. } \\
\text { OHE (n=18 client owned): A ventral midline incision was } \\
\text { made and the ovarian pedicles and uterus triple clamped } \\
\text { and double ligated with } 2-0 \text { or } 3-0 \text { PDS or polyglactin } 910 \\
\text { sutures, and transected. Abdominal closure was in three } \\
\text { layers. All surgery was performed by veterinary students } \\
\text { with a faculty vet for assistance. }\end{array}$ \\
\hline Study design: & Prospective, non-blinded, non-randomised, controlled trial \\
\hline Outcome studied: & $\begin{array}{l}\text { - Surgical time. } \\
\text { Pain scores at 0, 2, } 8 \text { and } 24 \text { hours postoperatively using a } \\
\text { subjective pain scoring system and UMPS in the } 28 \text { dogs } \\
\text { receiving the same analgesia at the end of surgery. } \\
\text { - Appearance of the wound. }\end{array}$ \\
\hline
\end{tabular}




\begin{tabular}{|c|c|}
\hline $\begin{array}{l}\text { Main findings: } \\
\text { (relevant to PICO question): }\end{array}$ & $\begin{array}{l}\text { - Mean pain scores for } 2 / 10 \text { dogs subjective descriptors (facial } \\
\text { expression and posture) were significantly lower for LOH } \\
\text { group for at least one time point. } \\
\text { Mean pain scores for } 8 / 10 \text { categories (UMPS) were } \\
\text { significantly lower for LOH group for at least one time point. }\end{array}$ \\
\hline Limitations: & 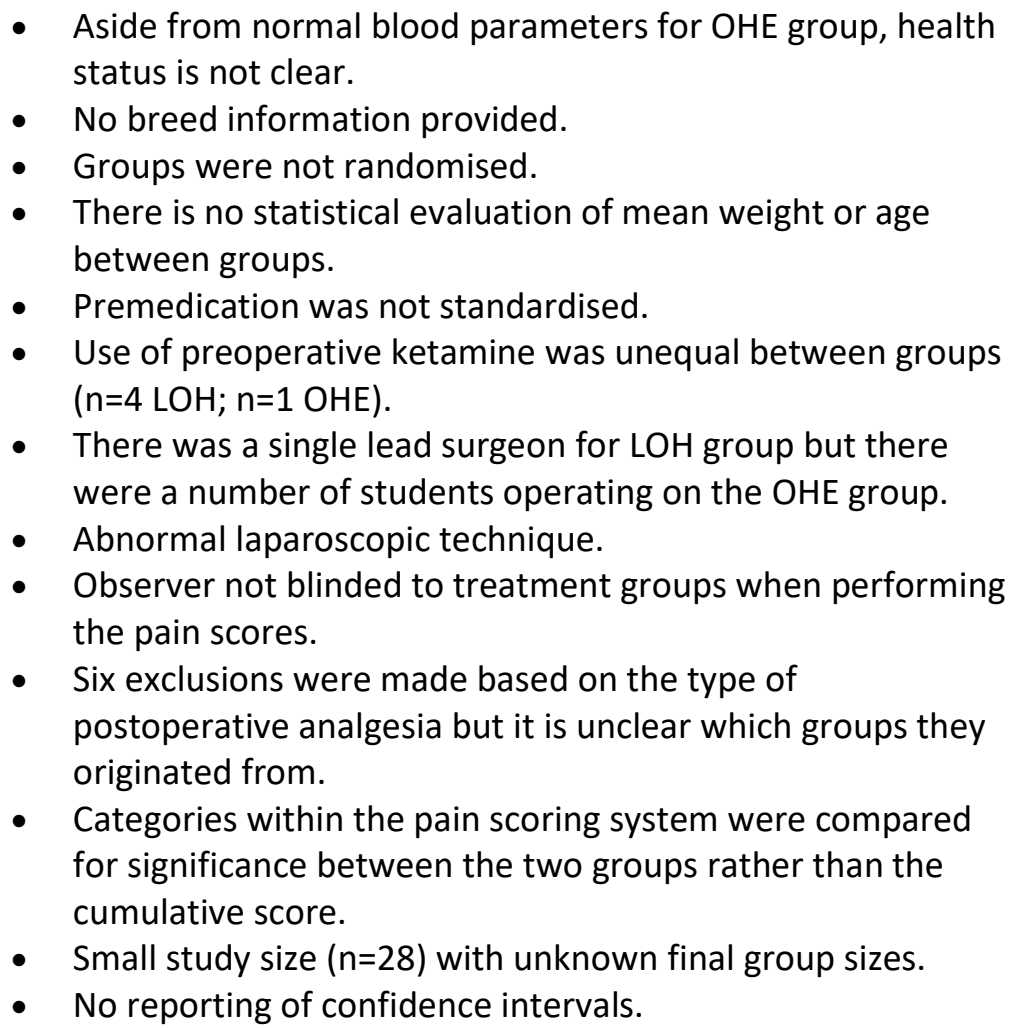 \\
\hline
\end{tabular}

\section{Appraisal, application and reflection}

A total of seven papers were appraised, comprising three blinded randomised controlled trials, two nonblinded randomised controlled trials and two non-blinded non-randomised controlled trials.

Whilst they supported the use of laparoscopy (to varying degrees) over traditional laparotomy by causing less postoperative pain, small patient numbers and the large variability between studies (and in some cases, groups) were significant constraints to the strength of evidence. Although each may be considered minimally invasive relative to their comparative (control) open procedure, the difference in laparoscopic technique across studies (i.e. port number, trocar size, method of access for pneumoperitoneum, insufflation pressures and variation in method of haemostasis) makes consideration as a single group very difficult. It is also worth noting that none of the referenced pain scoring systems used in these studies are validated for ovariectomy/ovariohysterectomy pain, but are commonly used in canine studies as a measure of postoperative pain.

In humans, laparoscopic techniques have been shown to cause less postoperative pain, shorten hospital admissions and ensure faster return to normal daily activity when compared with open surgery. As such, it is currently considered the gold standard approach for many gynaecological surgeries (Rajvinderet al. 2018). A common anatomy and physiology in pain processing between vertebrates (Pelligand \& Mora, 2016) would lead us to believe that a laparoscopic approach is also less painful in dogs. It is likely that smaller incisional wounds, as well as reduced tissue handling of sensitive structures, would be responsible for any difference seen in these patients. 
Underpowered studies (all seven studies here may be considered such) are typically associated with increased risk of false negative results (type II error) but will also increase the likelihood that statistically significant findings are false positives (type I error). Though either scenario would render any results misleading in the context of answering the clinical question, prior knowledge of human laparoscopic surgery would suggest that the probability of the null hypothesis (i.e. no significant difference in postoperative pain scores exists between laparoscopic and open ovariectomy/ovariohysterectomy) being true, is low. This would imply that there may still be some utility in significantly improved laparoscopic group pain scores.

The lowest risk of bias was found in the well-designed blinded randomised controlled trial by Hancock et al. (2005). Despite no age data, the purpose-bred population was considered homogeneous ensuring no difference between groups. Dogs were housed for 96 hours prior to surgery to limit the effects of stress on postoperative behaviour changes and pain scores. Although three different surgeons were responsible for intervention, block randomisation ensured that no surgeon performed an unequal number of surgeries in each group. A multidimensional composite pain scale (University of Melbourne pain scale (UMPS)) was combined with an objective nociceptive threshold measurement technique and assessed by a single (blinded) observer, removing interobserver bias. Statistics were performed appropriately, and confidence intervals recorded. Results showed significantly lower pain scores and higher nociceptive thresholds in dogs operated by laparoscopy. The strength of evidence is considered weak to moderate and could principally have been strengthened by larger group sizes.

Dalmolin et al. (2020) used blinded randomised controlled trial design with three pain scoring systems (including two multi parameter systems) but the benefit of multiple assessments was negated by using three pain assessors with only light to moderate agreement between them. Anaesthetic protocol was well controlled and a single surgeon was used for all procedures. The only significant differences in pain scores between groups showed the laparoscopic group to be more comfortable. There were, however, individual time points on each of the pain scoring systems where pain scores were lower for the laparotomy group. Significantly faster return to voluntary feeding was noted for the laparoscopy group which has previously been suggested as a sign of reduced postoperative pain (Sarrau et al., 2007). Unlike the other studies, ongoing pain medication was provided throughout the recovery period which would reduce differences in pain scores between groups. The benefit of laparoscopy over laparotomy appears limited using this analgesic combination but, again, this is an underpowered study. As such we believe that this study only provides weak evidence in favour of laparoscopy.

Devitt et al. (2005) used a non-blinded, randomised controlled trial design but with few other limitations. The main source of bias was in using two non-blinded observers to perform pain scoring. Reporting of breeds may have been beneficial but the weight and age of animals were well controlled. Standardisation of procedures was particularly rigorous (although there was limited description of the laparotomy technique), with the same surgeon and anaesthetic protocol for all animals. Statistical analysis was appropriate, with recording of confidence intervals. Pain scores and requirement for rescue analgesia (as well as neuroendocrine markers for some time points) were significantly higher in the dogs operated by laparotomy. The relative risk for rescue analgesia in the laparotomy was 10 fold, but the 95\% confidence interval was enormous (1.6 to 64.2) indicating an underpowered study. The pain scoring system was adapted from a system validated for use in human paediatric patients, not dogs. We therefore consider the strength of evidence in favour of laparoscopy to be weak.

A non-blinded, non-randomised controlled trial design was used by Freeman et al. (2010). Animals in both laparotomy and laparoscopy groups were from a local animal shelter and comparable in weight (though breeds and ages were not stated). Anaesthetic protocol was reportedly standardised (details of protocol not shown) but surgical team was unclear. Like Hancock et al. (2005), a combination of UMPS and nociceptive threshold testing was used, but two observers limit this strength. Reporting of statistics between laparoscopy and laparotomy was limited. The power calculation (the only study to report one) significantly overestimated 
the effect of the intervention group on reduction of IL-6, c-reactive protein (CRP), cortisol and increase in nociceptive threshold readings, this demonstrates the study is considerably underpowered.

Significantly lower pain scores and higher nociceptive thresholds were found in the laparoscopy group at certain time points. This may easily be missed as it is not reported in the results or discussion but is derived from the figures. We would consider this to be weak evidence in favour of laparoscopy.

Coutinho et al. (2018) used a blinded randomised controlled trial design but several limitations were encountered; principally two observers were responsible for pain scoring. Both UMPS and a visual analogue scale (VAS) were used, with the latter known to be more subjective (Pelligand \& Mora, 2016). The groups were assessed thoroughly before inclusion to ensure they were healthy, but breeds were not reported. Significantly faster return to eating (and in greater proportion) was found in the laparoscopy group, but this behaviour is not captured by any pain scoring system. Postoperative glucose concentrations (which Walsh et al. (1999) report to be a possible marker of stress caused by discomfort) were also significantly lower in dogs in this group, suggesting they may be more comfortable postoperatively than dogs operated by laparotomy. Although it was reported that no physiological parameters changed (suggesting no change in nociception) during the two complications in the laparoscopic group, the elimination of these from follow-up was an additional weakness. Given the lack of significant difference in pain scores combined with the above weaknesses, we cannot see this study being used as evidence to support use of laparoscopy over laparotomy to reduce postoperative pain.

Though Vasiljevic et al. (2015) also used a non-blinded, randomised controlled trial design, there was moderately high risk of bias. Aside from study design, a significant factor limiting the strength of evidence was the lack of recording. Species and approximate breed size of animals were stated, but we have no other information on group characteristics so are unable to confirm if they were comparable. The minimum patient age was 7 months and the smallest patient weight was $5 \mathrm{~kg}$, which does not fit with the description of medium and large breed dogs. Surgical team was not specified nor surgical techniques described, but there was a similar induction and maintenance protocol between groups. Additional analgesia was used for all patients in the laparotomy group but none in the laparoscopic group, which would bias the laparotomy group to lower postoperative pain scores (which was not the case). A single postoperative pain scoring method was used by one observer, based on four parameters to give a score from 0 to 9 (incorrectly presented in figures as 0 to 10). The parameters had similarities to the short form composite measure pain scale (CMPS-SF), but the description was brief and not referenced to other studies so was difficult to compare. Statistics were lacking but there is clear difference in pain scores between groups - much higher for dogs operated by laparotomy. This may, however, be a result of the reported slower recovery from general anaesthesia in the laparotomy group. Though unrelated to strength of evidence, ethics are of concern. The study was approved by the local ethics committee but no intervention level was set for rescue analgesia during the 6 hour assessment period. Two dogs were considered to be in severe pain at 1, 3 and 6 hours but analgesia was withheld until after the final pain score assessment. Overall concerns with reporting bias are significant and results must be viewed with skepticism and therefore this study cannot be used to answer the question in the clinical scenario.

A truly non-blinded non-randomised study was used by Davidson et al. (2004). The groups may not be comparable as there is no breed data, health status was not clear, and they were derived from different populations. In addition, there was no standardisation of anaesthetic protocol or surgical team between groups. The same surgeon was responsible for laparoscopic surgery, but multiple veterinary students (who are likely to have poorer tissue handling) performed open surgery, increasing bias in favour of laparoscopic techniques. We see that surgical times for OHE were as long as 140 minutes which is not consistent with what is typically expected* for this procedure. Equally, laparoscopic surgical times were significantly longer than expected, leading us to believe that this is a novel technique for the surgeon and the outcomes therefore unreliable. Ketamine $(6 \mathrm{mg} / \mathrm{kg}$ IV) was used preoperatively for four of the dogs undergoing laparoscopic surgery and only one of the dogs receiving open surgery. Preoperative use has been shown to confer significant postoperative analgesic effects (Slingsby \& Waterman-Pearson, 2000), so the results here are 
further biased. Unique to this study, a 4-port technique with a surgical wire ligation device was used. These techniques are not applicable for ovariectomy or ovariohysterectomy in general practice.

Although they report a number of parameters within the subjective pain scale and UMPS to be significantly higher for open surgery, this belies the lack of significant difference in overall scores. Overall, this study cannot be used to answer the question in the clinical scenario.

*Typical surgical times for laparotomy or laparoscopy would be 30-60 minutes depending on patient size.

Even in human surgery, we must remember that a laparoscopic approach is not without problems. Insufflation pressures above $15 \mathrm{mmHg}$, unnecessary pressure peaks and prolonged insufflation with $\mathrm{CO}_{2}$ have been shown to contribute to pain after laparoscopy in humans (Moulton et al., 1999).

In dogs, there is a suggestion that the rate of complications are reduced for laparoscopic ovariectomy compared with open ovariectomy (Charlesworth \& Sanchez, 2019), but experience in using the technique will affect the outcomes (Pope \& Knowles, 2014) along with surgical time. None of these factors, however, have been critically reviewed here but would require careful consideration when making recommendations for this technique.

Despite the widely held belief that laparoscopic surgery is associated with less postoperative pain, the available veterinary literature only provides weak evidence to support this in bitches undergoing ovariectomy/ovariohysterectomy. There are many uncontrolled variables to consider across the underpowered studies here including surgeon number (and experience), the choice of perioperative analgesia, method of pain scoring and the laparoscopic technique. It is therefore clear that laparoscopic procedures cannot be viewed equally and the strength of the answer to the clinical question may change based upon these variables.

\section{Methodology Section}

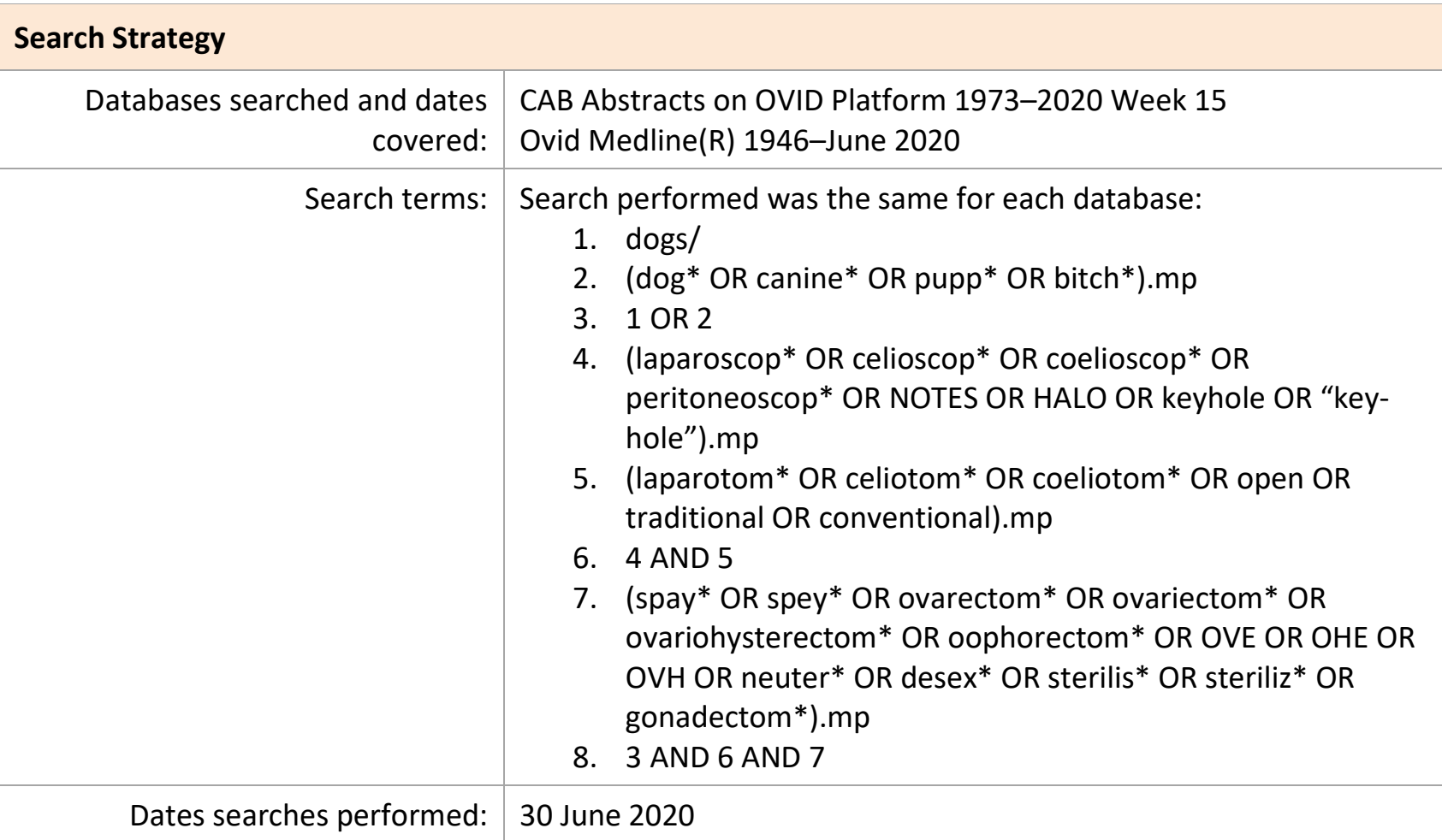




\begin{tabular}{|c|l|}
\hline Exclusion / Inclusion Criteria & \multicolumn{1}{|c|}{ Exclusion: } \\
& $\begin{array}{l}\text { Not available in English. } \\
\text { Reviews, letters, book chapters, case reports or conference } \\
\text { proceedings. } \\
\text { Species other than canines. } \\
\text { No report of outcomes relevant to postoperative pain. } \\
\text { Studies evaluating different laparoscopic techniques only. } \\
\text { Papers comparing laparoscopy to open flank approaches. } \\
\text { The NOTES technique was not considered as a comparison to open } \\
\text { procedures as it is not a technique that is currently widely used for } \\
\text { neutering in general practice - papers were not excluded if they still } \\
\text { compared a standard laparoscopic technique with open surgery. }\end{array}$ \\
\hline Inclusion: & $\begin{array}{l}\text { Comparison of midline open ovariectomy/ovariohysterectomy with } \\
\text { laparoscopic ovariectomy/ovariohysterectomy. } \\
\text { Laparoscopic techniques and methods considered reasonable in } \\
\text { general practice. This included any number of direct abdominal } \\
\text { ports for access, as well as the use of harmonic scalpel, mono- or bi- } \\
\text { polar electro surgery and suture, wire or clip ligation. } \\
\text { Studies that used a postoperative pain scoring system. }\end{array}$ \\
\hline &
\end{tabular}

\begin{tabular}{|c|c|c|c|c|c|}
\hline \multicolumn{6}{|c|}{ Search Outcome } \\
\hline Database & $\begin{array}{l}\text { Number of } \\
\text { results }\end{array}$ & $\begin{array}{l}\text { Excluded - } \\
\text { [Not English] }\end{array}$ & $\begin{array}{l}\text { Excluded - } \\
\text { [Review, case } \\
\text { report or } \\
\text { conference } \\
\text { proceedings] }\end{array}$ & $\begin{array}{c}\text { Excluded - [Did } \\
\text { not answer PICO] }\end{array}$ & $\begin{array}{c}\text { Total relevant } \\
\text { papers }\end{array}$ \\
\hline $\begin{array}{l}\mathrm{CAB} \\
\text { Abstracts }\end{array}$ & 92 & 29 & 14 & 43 & 6 \\
\hline Medline & 44 & 1 & 5 & 34 & 4 \\
\hline \multicolumn{5}{|c|}{ Total relevant papers when duplicates removed } & 7 \\
\hline
\end{tabular}

\section{CONFLICT OF INTEREST}

The authors declare no conflicts of interest. 
1. Charlesworth, T. M. \& Sanchez, F. T. (2019). A comparison of the rates of postoperative complications between dogs undergoing laproscopic and open ovariectomy. Journal of Small Animal Practice. 60(4), 218-222. DOI: https://doi.org/10.1111/jsap.12993

2. Coutinho, A. J., Gasser, B., Rodriguez, M. G. K., Uscategui, A. A. R., Santos, V. J. C., Tiosso, C. de F., Barros, F. F. P. da C. \& Toniollo, G. H. (2018). Comparison between single port videolaparoscopy and miniceliotomy with snook hot ovariohysterectomy techniques in bitches. Ciênca Rural. 48(10), e20180345. DOI: https://doi.org/10.1590/0103-8478cr20180345

3. Dalmolin, F., Oliveira, M. T., Filho, S. T. L. P., Vaz, M. A. B., de Cecco, B. S., Feranti, J. P. S., Carvalho, E. R., Silva, M. A. M. \& Brun, M. V. (2020). Dipyrone, Scopolamine, and meloxicam for conventional or two-port laparoscopic assisted ovariohysterectomy in female dogs. Semina: Ciências Agrárias (Londrina). 41(3), 887-896. DOI: https://dx.doi.org/10.5433/1679-0359.2020v41n3p887

4. Davidson, E. B., Moll, H. D. \& Payton, M. E. (2004). Comparison of Laparoscopic Ovariohysterectomy and Ovariohysterectomy in Dogs. Veterinary Surgery. 33(1), 62-69.

DOI: https://doi.org/10.1111/j.1532-950X.2004.04003.x

5. Devitt, C. M., Cox, R. E. \& Hailey, J. J. (2005). Duration, complications, stress, and pain of open ovariohysterectomy versus a simple method of laparoscopic-assisted ovariohysterectomy in dogs. Journal of the American Veterinary Medical Association. 227(6), 921-927.

DOI: https://doi.org/10.2460/javma.2005.227.921

6. Freeman, L. J., Rahmani, E. Y., Al-Haddad, M., Sherman, S., Chiorean, M. V., Selzer, D. J., Snyder, P. W. \& Constable, P. D. (2010). Comparison of pain and postoperative stress in dogs undergoing natural orifice transluminal endoscopic surgery, laparoscopic, and open oophorectomy. Gastrointestinal Endoscopy. 72(2), 373-380. DOI: https://doi.org/10.1016/i.gie.2010.01.066

7. Hancock, R. B., Lanz, O. I., Waldron, D. R., Duncan, R. B., Broadstone, R. V. \& Hendrix, P. K. (2005). Comparison of postoperative pain after ovariohysterectomy by harmonic scalpel-assisted laparoscopy compared with median celiotomy and ligation in dogs. Veterinary Surgery. 34(3), 273-282.

DOI: https://doi.org/10.1111/j.1532-950x.2005.00041.x

8. Khasriya, R., Vashisht, A. \& Cutner, A. (2018). Laparoscopy in urogynaecology. The Obstetrician and Gynaecologist. 20(2), 101-108. DOI: https://doi.org/10.1111/tog.12449

9. Mouton, W. G., Bessell, J. R., Otten, K. T. \& Maddern G. J. (1999). Pain after laparoscopy. Surgical Endoscopy. 13(5), 445-448. DOI: http://dx.doi.org/10.1007/s004649901011

10. Pelligand, L. \& Mora, S. S. (2016). Pain assessment methods. In: Duke-Novakovski T., de Vries M. \& Seymour C. (Eds.) BSAVA Manual of Canine an Feline Anaesthesia and Analgesia, Third Edition. Gloucester, UK. British Small Animal Veterinary Association, pp113-123.

11. Pope, J. F. A. \& Knowles, T. G. (2014). Retrospecitve Analysis of the Learning Curve Associated With Laparoscopic Ovariectomy in Dogs and Associated Perioperative Complication Rates. Veterinary Surgery. 43, 668-677. DOI: https://doi.org/10.1111/j.1532-950X.2014.12216.x

12. Sarrau, S., Jourdan, J., Dupuis-Soyris, F. \& Verwaerde, P. (2007). Effects of postoperative ketamine infusion on pain control and feeding behaviour in bitches undergoing mastectomy. Journal of Small Animal Practice. 48(12), 670-676. DOI: https://doi.org/10.1111/j.1748-5827.2007.00362.x

13. Slingsby, L. S. \& Waterman-Pearson, A. E. (2000). The postoperative analgesic effects of ketamine after canine ovariohysterectomy-a comparison between pre and postoperative administration. Research in Veterinary Science. 69(2), 147-152. DOI: https://doi.org/10.1053/rvsc.2000.0406

14. Vasiljević, M., Ristanović, D., Jovanović M., Davitkov, D., Bošnjak, I., Krstić, V. \& Stanimirović, Z. (2015) Comparative analysis of parameters of intraoperative and postoperative pain in bitches undergoing laparoscopic or conventional ovariectomy. Acta Veterinaria-Beograd. 65(4), 488-495. DOI: https://doi.org/10.1515/acve-2015-0041

15. Walsh, P. J., Remedios, A. M., Ferguson, J. F., Walker, D. D., Cantwell, S. \& Duke, T. (1999). Thoracoscopic versus open partial pericardectomy in dogs: Comparison of postoperative pain and morbidity. Veterinary Surgery. 28(6), 472-479. DOI: https://doi.org/10.1111/j.1532-950x.1999.00472.x 


\section{EVIIDEFeE

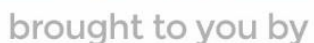 \\ RCVS KNOWLEDGE}

\section{Intellectual Property Rights}

Authors of Knowledge Summaries submitted to RCVS Knowledge for publication will retain copyright in their work, and will be required to grant RCVS Knowledge a non-exclusive license of the rights of copyright in the materials including but not limited to the right to publish, re-

publish, transmit, sell, distribute and otherwise use the materials in all languages and all media throughout the world, and to license or permit others to do so.

\section{Disclaimer}

Knowledge Summaries are a peer-reviewed article type which aims to answer a clinical question based on the best available current evidence. It does not override the responsibility

of the practitioner. Informed decisions should be made by considering such factors as individual clinical expertise and judgement along with patient's circumstances and owners' values. Knowledge Summaries are a resource to help inform and any opinions expressed within the Knowledge Summaries are the author's own and do not necessarily reflect the view of the RCVS Knowledge. Authors are responsible for the accuracy of the content. While the

Editor and Publisher believe that all content herein are in accord with current recommendations and practice at the time of publication, they accept no legal responsibility

for any errors or omissions, and make no warranty, express or implied, with respect to material contained within.

For further information please refer to our Terms of Use.

RCVS Knowledge is the independent charity associated with the Royal College of Veterinary Surgeons (RCVS). Our ambition is to become a global intermediary for evidence based veterinary knowledge by providing access to information

that is of immediate value to practicing veterinary professionals and directly contributes to evidence based clinical decision-making.

https://www.veterinaryevidence.org/

RCVS Knowledge is a registered Charity No. 230886.

Registered as a Company limited by guarantee in England and Wales No. 598443.

Registered Office: Belgravia House, 62-64 Horseferry Road, London SW1P 2AF

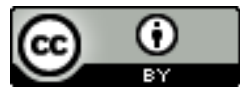

This work is licensed under a Creative Commons Attribution 4.0 International License 